\title{
PENGEMBANGAN PRODUK TAHU MENJADI TOFU CHIPS (KAJIAN JENIS BAHAN BAKU, SUHU PENGGORENGAN DAN BIAYA PRODUKSI)
}

\section{Ernawati}

\begin{abstract}
Abstrak: Tujuan Penelitian ini adalah untuk mendapatkan tofu chips yang baik dan disukai oleh konsumen berdasarkan pada pemilihan bahan baku dan penggunaan suhu penggorengan yang tepat. serta mendapatkan gambaran perencanaan produksi tofu chips ditinjau dari aspek finansial. Penelitian yang dilakukan merupakan gabungan dari penelitian dengan metode deskriptif dan eksperimental. Metode pelaksanaan penelitian meliputi : pembuatan tofu chips, uji kesukaan produk, produk terbaik, analisis kualitas, dan analisis finansial. Hasil Penelitian menunjukkan bahwa tofu chips yang dibuat dengan bahan baku tahu putih Malang, digoreng pada suhu $200^{\circ} \mathrm{C}$, terpilih sebagai produk terbaik dengan skor 2,653. Karakteristik produk terbaik yaitu berwarna kuning kecoklatan, dan memiliki rasa yang khas seperti bahan bakunya sedangkan karakteristik kimia produk adalah sebagai berikut kadar protein 20,57\%, kadar lemak 8,67, kadar air 0,0765 dan rendemen sebesar 29,06\%. Investasi awal yang dibutuhkan untuk mendirikan industri tofu chips dengan kapasitas produksi $128 \mathrm{~kg}$ per hari adalah sebesar Rp. 139.160.950,00. Harga Pokok Produksi (HPP) didapat sebesar Rp. 977,08 per kemasan dengan berat 100 gram, harga jual yang direncanakan sebesar Rp. 1400 dengan penambahan mark up sebesar 40\%, Break Even Point (BEP) terjadi pada volume penjualan 42517 kemasan senilai Rp. 59.344.554,46. Payback Periode (PP) adalah 3 tahun 9 bulan.
\end{abstract}

Kata kunci : pengembangan produk, tahu.

Tahu merupakan makanan tradisional Indonesia yang banyak dikonsumsi oleh masyarakat Indonesia karena harganya relatif murah dan memiliki kandungan gizi terutama protein yang tinggi, yaitu 10,9 gram per 100 gram tahu (Mahmud, dkk. 1990). Pola konsumsi masyarakat akan tahu telah berkembang. Tahu tidak hanya dikonsumsi sebagai lauk pauk, melainkan telah berkembang menjadi berbagai macam produk olahan seperti stik tahu. Pengolahan menjadi produk olahan lain sangat diperlukan karena tahu memiliki daya simpan yang rendah, disamping itu juga untuk meningkatkan nilai ekonomisnya.

Terdapat dua macam jenis tahu yaitu tahu putih dan tahu takwa kuning. Kedua macam tahu tersebut dibedakan berdasarkan cara pembuatannya. Pada tahu takwa kuning ditambahkan kunyit yang berfungsi sebagai pewarna dan juga dapat berfungsi sebagai pengawet, tekstur dari tahu kuning biasanya lebih 
padat jika dibandingkan dengan tahu putih biasa.

Produksi tahu dari tahun ketahun mengalami peningkatan. Berdasarkan penelitian Widyawati (1996), pada tahun 1989, kotamadya Kediri mempuyai 35 (tiga puluh lima) perusahaan tahu. Jumlah ini terus meningkat menjadi 54 perusahaan dalam tahun 1992, demikian pula pada perusahaan tahu merk "Sari Lezat POO", tahun 1989 mempuyai kapasitas produksi 130.000 biji/ bulan, pada tahun 1995 meningkat menjadi 300.000 biji/ bulan. Sedangkan di kota Malang pada tahun 2005, terdapat 8 industri tahu formal dengan kapasitas produksi $673.900 \mathrm{~kg}$ (Desperindag 2005). Peningkatan kapasitas produksi tahu tiap tahun memungkinkan untuk dikembangkan menjadi produk olahan lain, sehingga nilai ekonomis tahu dapat meningkat dan pasar tidak menggalami kejenuhan .

Alternatif baru dalam pengembangan produk tahu adalah kripik. Kripik adalah makanan ringan (snack food) yang tergolong jenis makanan crackers, yaitu makanan yang bersifat kering, renyah (crispy), dan memiliki kandungan lemaknya tinggi (Sulistyowati, 2004). Produk kripik sangat digemari oleh masyarakat. Berdasarkan data BPS Jawa Timur menyebutkan tingkat konsumsi per kapita untuk produk makanan ringan yang digolongkan ke dalam krupuk, emping, dan snack di Jawa Timur pada tahun 2002 mencapai 63 gram per kapita per minggu (Anonymous, 2003).
Kripik tahu (tofu chips) mempuyai kelebihan dibandingkan kripik lain berdasarkan bahan bakunya, yaitu memiliki kandungan protein dan lemak yang tinggi.

Berdasarkan penjelasan tersebut tahu memiliki peluang yang cukup bagus untuk dikembangkan menjadi kripik (tofu chips). Pada penelitian pengembangan tahu menjadi produk tofu chips ini ditekankan pada bagaimana proses pengolahan tofu chips ditinjau dari suhu pengorengan dan bahan baku tahu yang digunakan, karena diketahui suhu pengorengan yang tinggi dapat menyebabkan kandungan protein tahu dapat terdenaturasi. Menurut Apriyanto (2002), kebanyakan protein pangan terdenaturasi jika dipanasakan pada suhu yang moderat $\left(60-90^{\circ} \mathrm{C}\right)$ selama satu jam atau kurang dan bagaimana analisis biaya produksinya.

\section{METODE PENELITIAN}

Penelitian yang dilakukan merupakan gabungan dari penelitian dengan metode deskriptif dan eksperimental. Penelitian diskriptif dilakukan untuk mengetahui lebih lanjut mengenai tofu chips, potensi bahan baku, tingkat penerimaan konsumen dan potensi pasar. Penelitian eksperimental dilakukan untuk mendapatkan produk tofu chips yang dapat diterima oleh konsumen.

\section{Penelitian Deskriptif}

Penelitian ini dilaksanakan di sumber data sekunder seperti BPS kota 
Malang, BPS Kediri, Dinas Perindustrian dan Perdagangan (Disperindag) kota Kediri, Disperindag kota Malang. Caprina Malang, produsen stik tahu Kediri dan studi literature di perpustakaan Universitas Brawijaya Malang mulai bulan MeiJuli 2009.

\section{Penelitian Eksperimental}

Penelitian ini dilakukan di Laboratorium Rekayasa Proses dan Sistem Produksi, Jurusan Teknologi Industri Pertanian, Fakultas Teknologi Pertanian, Universitas Brawijaya Malang, pada bulan Mei sampai dengan Juni 2009.

\section{Metode Pelaksanaan Penelitian}

Metode pelaksanaan penelitian terbagi atas pembuatan tofu chips, analisa kualitas, penerimaan konsumen, produk terbaik, dan analisa kelayakan finansial dari produk tofu chips terbaik.

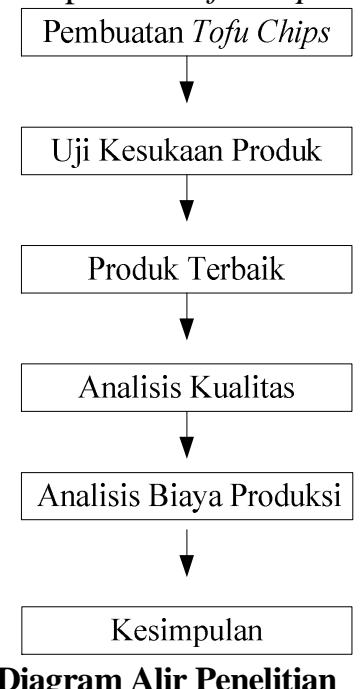

Pembuatan Tofu Chips

Pembuatan tofu chips dilakukan menggunakan 2 faktor. Faktor 1 terdiri dari 2 level dan faktor 2 terdiri dari 3 level.

Faktor-faktor yang digunakan adalah:

Faktor I : Jenis Tahu

$S_{1}$ : Tahu Putih Malang

$\mathrm{S}_{2}$ : Tahu Takwa Kediri

Faktor II : Suhu Penggorengan

$\mathrm{T}_{1}: 180^{\circ} \mathrm{C}$

$\mathrm{T}_{2}: 190^{\circ} \mathrm{C}$

$\mathrm{T}_{3}: 200^{\circ} \mathrm{C}$

Dari dua faktor tersebut dapat diperoleh kombinasi perlakuan sebagai berikut:

$\mathrm{S}_{1} \mathrm{~T}_{1}$ : Tahu Putih Malang dan Suhu Penggorengan $180^{\circ} \mathrm{C}$

$\mathrm{S}_{1} \mathrm{~T}_{2}$ : Tahu Putih Malang dan Suhu Penggorengan $190^{\circ} \mathrm{C}$

$\mathrm{S}_{1} \mathrm{~T}_{3}$ : Tahu Putih Malang dan Suhu Penggorengan $200^{\circ} \mathrm{C}$

$\mathrm{S}_{2} \mathrm{~T}_{1}$ : Tahu Takwa Kediri dan Suhu Penggorengan $180^{\circ} \mathrm{C}$

$\mathrm{S}_{2} \mathrm{~T}_{2}$ : Tahu Takwa Kediri dan Suhu Penggorengan $190^{\circ} \mathrm{C}$

$\mathrm{S}_{2} \mathrm{~T}_{3}$ : Tahu Takwa Kediri dan Suhu Penggorengan $200^{\circ} \mathrm{C}$

\section{Uji Kesukaan Produk}

Untuk mengetahui tingkat kesukaan terhadap produk tofu chips dilakukan dengan menggunkanan uji organoleptik. Uji organoleptik yang direncanakan dilakukan oleh 5 orang panelis ahli dari produsen makanan ringan, antara lain yaitu Caprina Malang, produsen stik dan tahu Tinalan Kediri, produsen stik dan tahu Mikimos Kediri. Uji yang 
dilakukan meliputi rasa, warna, dan kerenyahan dengan menggunakan metode "Hedonic Scale" (Meilgard, 1999).

\section{Pemilihan Produk terbaik}

Perlakuan terbaik adalah perlakuan dengan skor nilai tertinggi dari derajat kepentingan produk yang diharapkan oleh konsumen. Proses pengambilan keputusan perlakuan terbaik dilakukan dengan indeks effektivitas (DeGarmo, dkk. 1987).

Prosedur perhitungan indeks effektivitas adalah sebagai berikut:

a. Memberikan bobot nilai pada masing-masing variabel dengan angka relatif $0-1$. bobot nilai yang diberikan tergantung dari kepentingan masing-masing variabel yang hasilnya diperoleh dari perlakuan.

b. Membagi variabel menjadi 2 kelompok,

1. Kelompok A terdiri dari variabelvariabel yang makin tinggi reratanya semakin baik, meliputi kadar protein, kadar lemak, rendemen.

2. Kelompok B terdiri dari variablevariabel yang makin tinggi reratanya semakin jelek seperti kadar air

c. Mencari bobot normal dari masingmasing parameter, yaitu bobot parameter dibagi bobot total.

\section{Nilai total tiap Parameter}

Bobot $=$

Nilai total seluruh parameter

d. Menghitung nilai effektivitas dengan rumus:

$$
N E=\frac{N p-N t j}{N t b-N t j}
$$

Keterangan :

$$
\begin{aligned}
\mathrm{NE} & =\text { Nilai Effektivitas } \\
\mathrm{Np} & =\text { Nilai Perlakuan } \\
\mathrm{Ntj} & =\text { Nilai Terjelek } \\
\mathrm{Ntb} & =\text { Nilai Terbaik }
\end{aligned}
$$

e. Untuk parameter dengan rerata semakin besar semakin baik, maka nilai terendah sebagai nilai terjelek dan nilai tertinggi sebagai nilai terbaik, demikian juga sebaliknya.

f. Menghitung nilai perlakuan (NP) yang diperoleh dari hasil perkalian bobot normal dengan nilai effektivitas (NE).

\section{$\mathrm{NH}=\mathrm{NP} \times$ Bobot}

g. Menjumlahkan nilai hasil dari semua parameter perlakuan yang memiliki nilai hasil tertinggi adalah perlakuan terbaik pada kelompok parameter.

h. Perlakuan terbaik dipilih dari perlakuan yang memiliki NP tertinggi.

\section{Analisa Kualitas}

Analisis Kualitas yang dilakukan meliputi kadar lemak, kadar air, kadar protein, dan rendemen yang diperoleh. 
Pelaksanaan pengamatan terhadap parameter-parameter tersebut dilaksanakan dengan menggunakan cara sebagai berikut:

- Kadar lemak (AOAC, 1975 dalam Sudarmadji dkk, 1984).

- Kadar air (AOAC, 1975 dalam Sudarmadji dkk, 1984).

- Kadar protein (AOAC, 1975 dalam Sudarmadji dkk, 1984).

- Rendemen (Suryanto, 2000).

\section{Analisa Biaya Produksi}

Analisis biaya produksi dilakukan untuk mengetahui apakah produk tofu chips terpilih, layak untuk direncanakan dan dikembangkan menjadi suatu industri. Analisis biaya produksi dilakukan dengan menggunakan Break Even Point (BEP) dan Payback Periods (PP) (Mulyadi, 1997).

\section{HASIL PENELITIAN \\ STUDI PENGEMBANGAN \\ PRODUK}

\section{Potensi Bahan Baku}

Bahan baku merupakan elemen yang sangat penting pada proses produksi, ketersediaan dan kontinuitas bahan baku sangat berpengaruh pada proses produksi. Bahan baku industri tofu chips di Jawa Timur menyebar diberbagai daerah. Salah satu sentra industri tahu yang besar dan dikenal oleh masyarakat Jawa Timur adalah di wilayah kota Kediri. Selain di kota Kediri juga banyak terdapat di berbagai kabupaten yang ada di wilayah Jawa Timur misalnya di kabupaten Malang dan sekitarnya.
Bahan baku yang digunakan pada industri tofu chips yang direncanakan adalah tahu putih Malang. Menurut Badan Pusat Statistik di wilayah Jawa Timur terdapat lebih dari 50 industri tahu yang menyebar di wilayah kota Malang dan Surabaya. Data di Desperindag kota Malang menunjukkan pada tahun 2005, terdapat 8 industri tahu formal dengan kapasitas produksi $673.900 \mathrm{~kg}$ atau setara dengan 673,9 ton per tahunnya. sedangkan di wilayah kabupaten Kediri sendiri terdapat 27 industri tahu formal dengan kapasitas produksi total 7.991 .900 potong/ bulan dan juga terdapat industri tahu non formal sebanyak 22 buah dengan kapasitas produksi total 7.239.000 potong/ bulan. (Disperindag, 2004).

\section{Potensi Pasar}

Pasar dari produk tofu chips yang dituju adalah masyarakat yang gemar mengkonsumsi makanan ringan mulai dari anak-anak sampai dewasa. Berdasarkan data Badan Pusat Statistik (BPS) Jatim pada tahun 2002 tingkat konsumsi per kapita untuk produk makanan ringan yang digolongkan ke dalam krupuk, emping, dan snack mencapai 63 gram per kapita per minggu atau $3,276 \mathrm{~kg}$ per kapita per tahun. dengan jumlah penduduk Jawa Timur sebanyak 34.783 .640 jiwa (2003), maka jumlah konsumsi makanan ringan penduduk Jawa Timur mencapai 113.951.205 kg per tahun (Anonymous, 2003). Pasar yang cukup luas tersebut memungkinkan untuk menjadi dasar dalam pengembangan 
makanan ringan yang mempuyai kandungan nutrisi dan gizi bahan yang cukup.

Potensi pasar makanan ringan yang sangat besar tersebut terbagi atas krupuk, emping dan snack, sedangkan kripik sendiri oleh Badan Pusat Statistik (BPS) digolongkan kedalam kategori krupuk. Dari potensi pasar yang tersedia, tofu chips direncanakan diproduksi dengan kapasitas produksi $38.400 \mathrm{~kg}$ per tahunnya atau sekitar $0,03 \%$ dari potensi pasar yang tersedia. Kapasitas produksi ditetapkan berdasarkan pertimbangan ketersediaan modal kerja dan fasilitas mesin dan peralatan yang dimiliki oleh perusahaan.

Segmen pasar yang dituju untuk pertama kalinya hanya masyarakat Jawa Timur dengan pertimbangan sedikitnya biaya distribusi produk yang diperlukan, karena daerah Jawa Timur ini berdekatan dengan perusahaan yang memproduksi produk tofu chips yang direncanakaan di kota Malang, disisi lain jumlah penduduk Jawa Timur yang relatif banyak sehingga daerah ini cukup memenuhi untuk dijadikan sebagai daerah awal untuk uji coba produk tofu chips sebelum memproduksi dengan kapasitas produksi yang lebih besar lagi. Hal ini karena dalam proses komersialisasi perusahaan dapat memilih strategi geografis untuk mencapai target pasar yang diinginkan (Kotler, 2002)

\section{HASIL UJI KESUKAAN Tofu Chips Pembobotan Kriteria}

Pembobotan kriteria merupakan tahapan untuk menentukan tingkat kepentingan dari atribut-atribut yang ada pada produk. Pada penelitian ini atribut produk yang digunakan untuk menilai atau menentukan produk terpilih merupakan atribut-atribut yang dapat dinilai dan dirasakan secara langsung oleh indera manusia. Hal ini disebabkan, secara umum konsumen menggunakan indera yang dimilikinya, untuk menilai dan memilih produk makanan yang akan dikonsumsinya, terutama terhadap produk-produk yang baru dikenalnya. Menurut Budiman (1985), beberapa sifat penting yang menentukan penilaian seseorang terhadap produk yang digoreng seperti kripik adalah kenampakan (warna), flavour (rasa dan aroma), dan tekstur (kerenyahan). Data hasil pembobotan kriteria yang telah dilakukan oleh panelis pada produk tofu chips dapat dilihat pada Tabel dibawah.

\section{Data Hasil Pembobotan Kriteria Tofu Chips}

\begin{tabular}{|c|c|c|c|c|}
\hline \multirow{2}{*}{ Panelis } & \multicolumn{3}{|c|}{ Parameter } & \multirow{2}{*}{ Total } \\
\cline { 2 - 4 } & Warna & Rasa & Kerenyahan & \\
\hline 1 & 3 & 2 & 1 & 6 \\
\hline 2 & 1 & 3 & 2 & 6 \\
\hline 3 & 1 & 3 & 2 & 6 \\
\hline 4 & 2 & 3 & 1 & 6 \\
\hline 5 & 1 & 3 & 2 & 6 \\
\hline Total & 8 & 14 & 8 & 30 \\
\hline Bobot & 0.2667 & 0.4667 & 0.266667 & 0 \\
\hline
\end{tabular}

Keterangan :

Panelis 1. Pemilik industri tahu dan stik Mikimos Jl. Patimura 59 
Panelis 2 Karyawan industri tahu dan stik Mikimos Jl. Patimura 59

Panelis 3. Pemilik industri tahu dan stik tinalan IV/47 Kediri

Panelis 4. Karyawan industri tahu dan stik tinalan IV/47 Kediri

Panelis 5. Pemilik Caprina Tlogomas Malang

Dari Tabel diatas dapat dilihat bobot tiap-tiap kriteria yang melekat pada tofu chips antara lain yaitu warna memiliki skor 0,26 , rasa memiliki skor 0,46, kerenyahan memiliki skor 0,26 , disini terlihat kriteria rasa memiliki bobot yang paling tinggi dan selanjutnya diikuti oleh kerenyahan dan warna produk. Hal ini karena panelis memilih rasa sebagai kriteria produk yang paling penting, dengan alasan bahwa rasa merupakan indikasi awal yang dapat dirasakan oleh indra manusia untuk menilai suatu produk makanan. Ada juga panelis yang memberikan skor tertinggi pada warna produk dengan alasan, konsumen akan menilai suatu produk dari kenampakan visual dulu, baru rasa dan kerenyahan produk.

\section{Uji Kesukaan Terhadap Kriteria Warna}

Warna merupakan respon mata manusia terhadap sinar (Soekarto, 1985). Produk makanan dapat memantulkan sinar, sehingga dapat dilihat oleh mata manusia. Warna yang ditimbulkan makanan dapat menimbulkan ketertarikan tersendiri bagi konsumen untuk mengkosumsinya. Pada Gambar dibawah dapat dilihat data rata-rata penilaian panelis terhadap warna tofu chips.

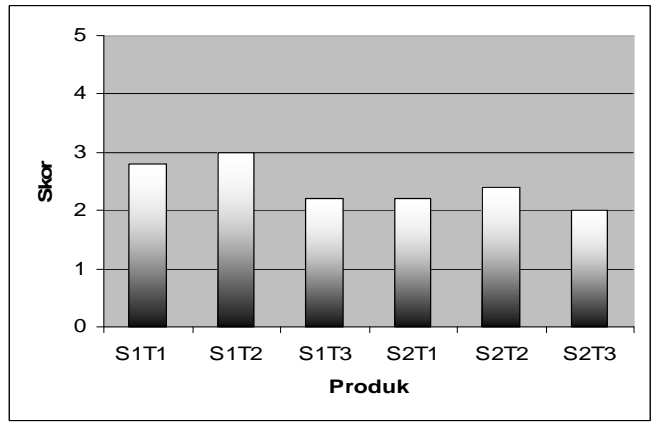

Grafik Rata-Rata Penilaian Panelis Terhadap Warna Tofu Chips

Pada grafik diatas terlihat penilaian panelis terhadap warna tofu chips rata- rata nilai kesukaan berkisar antara 2 sampai 3, panelis paling menyukai warna pada perlakukan yang kedua yaitu tofu chips yang berbahan baku dari tahu putih malang, dan digoreng pada suhu $190^{\circ} \mathrm{C}$. ini menunjukkan bahwa jenis bahan baku dan suhu pengorengan sangat berpengaruh terhadap warna tofu chips. Bahan baku tahu putih malang bila digoreng pada suhu $190^{\circ} \mathrm{C}$, akan menghasilkan warna putih kekuningan. Kombinasi warna seperti ini yang disukai oleh konsumen, hal ini karena apabila suhu di turunkan akan menghasilkan warna agak pucat dan sebaliknya apabila suhu penggorengan ditingkatkan akan menyebabkab kegosongan dan menghasilkan warna agak kecoklatan.

Timbulnya warna pada permukaan bahan disebabkan oleh reaksi browning artau reaksi maillard. Tingkat intensitas warna tergantung dari lama dan suhu menggoreng dan 
juga komponen kimia pada permukaan luar dari bahan pangan sedangkan jenis lemak yang digunakan berpengaruh sangat kecil terhadap warna permukaan bahan pangan (Ketaren, 1986).

\section{Rasa}

Penilaian terhadap rasa (flavour) pada makanan, pada dasarnya tidak hanya dirasakan oleh indera pencicip saja. Rasa makanan tersebut, merupakan campuran dari tanggapan cicip, bau, dan yang ditimbulkan oleh kesan-kesan lain seperti penglihatan, sentuhan, dan pendengaran. Jadi, ketika kita merasakan makanan, sebenarnya kenikmatan tersebut diwujudkan bersama-sama oleh kelima indera (Soekarto, 1985). Pada Gambar di bawah dapat dilihat data rata-rata penilaian panelis terhadap rasa tofu chips.

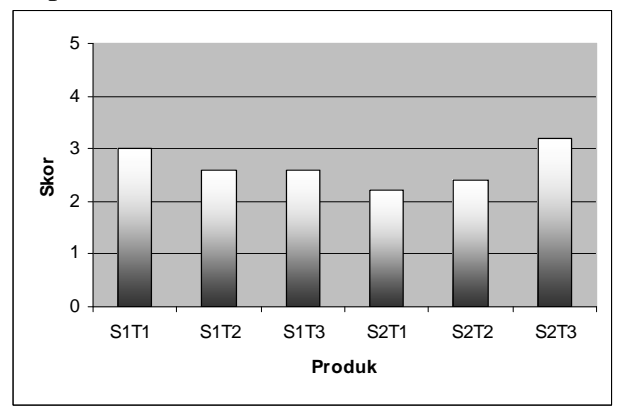

Grafik Rata-Rata Penilaian Panelis Terhadap Rasa Tofu Chips

Pada grafik diatas terlihat penilaian panelis terhadap rasa tofu chips, rata- rata nilai kesukaan berkisar antara 2,2 sampai 3,2, panelis paling menyukai rasa pada perlakuan yang keenam yaitu tofu chips yang berbahan baku dari tahu takwa yang digoreng pada suhu $200^{\circ} \mathrm{C}$. Tofu chips yang dihasilkan pada perlakuan ini disukai konsumen dengan alasan bahwa kalau dilihat dari bahan bakunya, tahu takwa sudah memiliki rasa yang khas sedangkan tahu putih tidak berasa, disamping itu suhu pengorengan yang cocok dalam pengolahan makanan akan dapat meningkatkan cita rasa produk. Menurut Fellow(2000), faktor utama yang mempengaruhi warna, rasa dan bau adalah jenis minyak goreng yang digunakan, suhu penyimpanan minyak, suhu dan lama penggorengan, ukuran, kelembaban dan penampakan dari makanan serta perlakuan setelah penggorengan.

\section{Kerenyahan}

Kerenyahan suatu produk makanan dapat dinilai berdasarkan bunyi yang dihasilkan bila produk dipatahkan. Biasanya untuk produk yang semakin renyah akan menghasilkan bunyi yang lebih nyaring (Vickers, 1979). Kerenyahan pada produk seperti keripik juga dapat dirasakan ketika produk itu digigit. Pada Gambar di bawah dapat dilihat data rata-rata penilaian panelis terhadap kerenyahan tofu chips. 


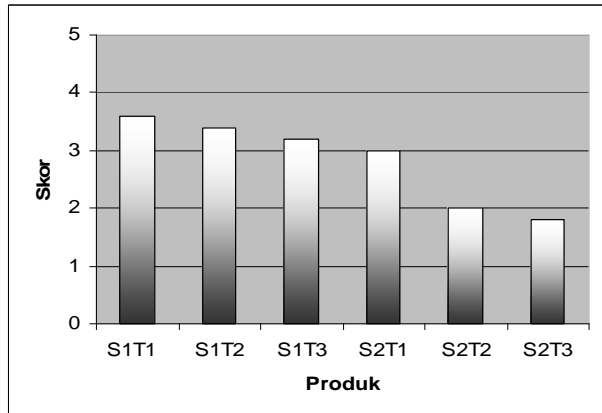

Grafik Rata-Rata Penilaian Panelis Terhadap Kerenyahan Tofu Chips

Pada grafik diatas terlihat penilaian panelis terhadap kerenyahan tofu chips, rata- rata nilai kesukaan berkisar antara 1,8 sampai 3,6, panelis paling menyukai tofu chips pada perlakuan pertama yaitu tofu chips yang berbahan baku dari tahu putih dan digoreng pada suhu $180^{\circ} \mathrm{C}$. Panelis memilih tofu chips yang dihasilkan pada perlakuan pertama ini dengan alasan suhu yang terlalu tinggi pada proses penggorengan dapat menyebabkan tingkat kehilangan kadar air bahan terlalu banyak sehingga akan dapat mempengaruhi rasa dan tingkat kerenyahan produk. Panelis beranggapan pada suhu $180^{\circ} \mathrm{C}$ tingkat kerenyahan tofu chips sudah dapat dicapai dengan baik

Pada makanan kering seperti keripik, timbulnya bunyi disebabkan adanya rongga antar sel yang kaku dan rapuh yang berisi udara (Vickers, 1979). Selain itu, tingkat kerenyahan berhubungan erat dengan kadar air produk. Pada kadar air yang terlalu tinggi menjadikan tekstur kurang garing/tidak renyah (Muchtadi dkk., 1987). Kerenyahan juga berhubungan dengan daya patah. Daya patah merupakan besarnya usaha yang dilakukan untuk mematahkan produk. Semakin rendah nilai daya patah maka akan semakin meningkatkan nilai kerenyahannya.

\section{Produk Terbaik}

Pemilihan alternatif Produk terbaik dilakukan dengan menggunakan metode Indeks Effektivitas. Menurut De Garmo, Sullivan, and Canada (1984), keuntungan penggunaan indeks effektivitas adalah:

a. Dapat dipakai untuk alternatif yang memiliki banyak kriteria. Masingmasing kreteria atau atribut dapat berbeda tingkat kepentingannya (dinyatakan dengan bobot).

b. Mudah divisualisasikan dan cukup sederhana.

Berdasarkan dari kuisioner tingkat kepentingan kriteria yang diberikan pada panelis, diperoleh hasil bobot tertinggi pada kriteria rasa dengan bobot 0,466 kemudian diikuti kerenyahan dan warna produk memiliki bobot yang sama yaitu 0,266. Perhitungan pembobotan kriteria dapat dilihat pada lampiran 4. Setelah diketahui bobot tiap kriteria, selanjutnya dilakukan perhitungan nilai efektifitas untuk mendapatkan nilai produk. Berdasarkan hasil perhitungan, diperoleh nilai produk tertinggi pada perlakuan S1T3 (Jenis Bahan Baku Tahu Putih ; Suhu Penggorengan 
$200^{\circ} \mathrm{C}$ ) yang akan menghasilkan tofu chips dengan kadar protein $20,57 \%$, kadar lemak 8,67 \%, kadar air 0,076 \%, dan rendemen sebesar $29,06 \%$.

\section{KUALITAS PRODUK}

Karakteristik Tofu Chips yang

\section{Dihasilkan}

Kripik tahu (tofu chips) yang dihasilkan berbentuk segi empat dengan lebar $1,5 \mathrm{~cm}$ x $1,5 \mathrm{~cm}$ dengan ketebalan $1 \mathrm{~mm}$ sedangkan kenampakan visual produk relatif sama, berwarna kuning kecoklatan. Sedangkan tingkat kerenyahan produk bervariasi antara satu dengan yang lain, aroma produk memiliki aroma yang khas seperti pada bahan bakunya.

Tofu chips Jika dibandingkan dengan produk makanan ringan yang lainnya mempuyai kelebihan memiliki kandungan protein yang cukup tinggi. Dari hasil penelitian terlihat kadar protein yang terkandung bervariasi untuk tiap jenis bahan baku yang digunakan. Untuk tahu putih berkisar antara 20,57 - 23,73 \% sedangkan untuk tahu takwa kuning berkisar antara 22,43- $25,95 \%$.

Hasil Analisis Kimia Produk Tofu Chips
Karakteristik Kimia Produk Tofu Chips

Berdasarkan hasil analisa kimia yang telah dilakukan terhadap produk tofu chips diperoleh hasil sebagai berikut :

Hasil uji kimia yang terlihat pada Tabel diatas menunjukkan bahwa peningkatan suhu penggorengan dapat menyebabkan kadar protein, kadar lemak produk menjadi turun. Suhu yang tinggi pada pengolahan makanan dapat menyebabkan terdenaturasinya kandungan protein produk sehingga menyebabkan menurunnya kandungan protein bahan, hal ini sesuai dengan pendapat Apriyanto (2002), yang menyatakan kebanyakan protein pangan terdenaturasi jika dipanasakan pada suhu yang moderat $\left(60-90^{\circ} \mathrm{C}\right)$ selama satu jam atau kurang.

Dari data tersebut diatas menunjukkan kadar protein tertinggi adalah sebesar 25,95 \% (pada penggorengan suhu $180^{\circ} \mathrm{C}$ untuk jenis bahan baku tahu takwa kuning) dan terendah adalah 20,57 \% (pada penggorengan suhu $200^{\circ} \mathrm{C}$, jenis bahan baku tahu putih). Untuk kadar lemak tertinggi adalah sebesar $16,03 \%$ (pada penggorengan suhu $180^{\circ} \mathrm{C}$ untuk jenis

\begin{tabular}{|l|c|c|c|}
\hline \multicolumn{1}{|c|}{ Perlakuan } & $\begin{array}{c}\text { Kadar } \\
\text { Protein }\end{array}$ & $\begin{array}{c}\text { Kadar } \\
\text { Lemak }\end{array}$ & Kadar Air \\
\hline Tahu Putih, Suhu $180^{\circ} \mathrm{C}$ & 23.73 & 12.4 & 0.152 \\
\hline Tahu Putih, Suhu $190^{\circ} \mathrm{C}$ & 21.05 & 9.29 & 0.091 \\
\hline Tahu Putih, Suhu $200^{\circ} \mathrm{C}$ & 20.57 & 8.67 & 0.076 \\
\hline Tahu Takwa, Suhu $180^{\circ} \mathrm{C}$ & 25.95 & 16.03 & 0.136 \\
\hline Tahu Takwa, Suhu $190^{\circ} \mathrm{C}$ & 24.74 & 11.03 & 0.108 \\
\hline Tahu Takwa, Suhu $200^{\circ} \mathrm{C}$ & 22.43 & 9.26 & 0.064 \\
\hline
\end{tabular}


bahan baku tahu takwa kuning) dan terendah adalah 8,67 \% (pada penggorengan suhu $200^{\circ} \mathrm{C}$, jenis bahan baku tahu putih), sedangkan untuk kadar air tertinggi adalah sebesar 0,152 $\%$ (pada penggorengan suhu $180^{\circ} \mathrm{C}$ untuk jenis bahan baku tahu putih ) dan terendah adalah $0.064 \%$ (pada penggorengan suhu $200^{\circ} \mathrm{C}$, jenis bahan baku tahu takwa kuning).

\section{TEKNOLOGI PROCCESING TOFU CHIPS}

\section{Gambaran Teknologi Proccesing Tofu Chips}

Teknologi yang digunakan dalam pembuatan tofu chips relatif sederhana, peralatan yang digunakan juga tidak terlalu mahal dan sulit untuk diperoleh, dan juga modal kerja yang diperlukan tidak terlalu banyak, sehingga produk ini tidak sulit untuk dikembangkan pada skala usaha kecil menengah (UKM). Tahapan proses pembuatan tofu chips adalah sebagai berikut :

a) Pecucian

Tahu yang akan digunakan sebagai bahan baku dalam pembuatan tofu chips, dicuci dan direndam dengan tujuan untuk membersihkan bahan dan untuk menghilangkan bau asam pada tahu.

b) Penghancuran dan pengepresan

Proses ini bertujuan untuk mengurangi kadar air pada bahan baku tahu, mempermudah pada perlakuan selanjutnya, mengurangi jumlah penambahan tepung dan meningkatkan kadar protein produk c) Pengadukan

Bahan baku tahu yang telah dipres selanjutnya ditambah dengan tepung terigu, tepung kaji dengan perbandingan $1: 10$ untuk masingmasing tepung, dan ditambah bumbu sebagai penyedap rasa, selanjutnya diaduk sampai terbentuk adonan yang homongen.

d) Pengukusan

Pengukusan ini bertujuan untuk membantu dalam proses gelatinisasi bahan. Pengukusan merupakan unit operasi yang bertujuan untuk mencapai gelatinisasi pati yang sempurna makanan (Luh, 1980).

e) Pengilingan dan Pemotongan

Adonan yang telah dikukus, digiling menjadi lembaranlembaran tipis dengan ketebalan 1 $\mathrm{mm}$, kemudian dipotong dengan lebar $1,5 \times 1,5 \mathrm{~cm}$.

f) Pengeringan

Pengeringan dilakukan selama 18 jam pada suhu $50^{\circ} \mathrm{C}$ dengan tujuan untuk menggurangi kadar air dan kelembaban pada bahan. Tipe pengering yang digunakan adalah Pengering kabinet (CabinetDrying).

g) Pengorengan

Tofu Chips yang masih mentah dan sudah dikeringkan selama 4 jam selanjutnya digoreng dengan menggunkan Deep Frying. Suhu penggorengan yang digunakan dibagi menjadi 3 level yaitu : 180, $190,200^{\circ} \mathrm{C}$. 
h) Penirisaan

Penirisan dilakukan dengan tujuan untuk menggurangi kadar minyak goreng yang terserap pada saat penggorengan, kerenyahan bahan, dan juga memperlama waktu simpan produk.

i) Pengemasan

Pengemasan dilakukan dengan menggunakan alumunium foil, dengan pertimbangan bahan ini mempuyai kekedapan udara yang

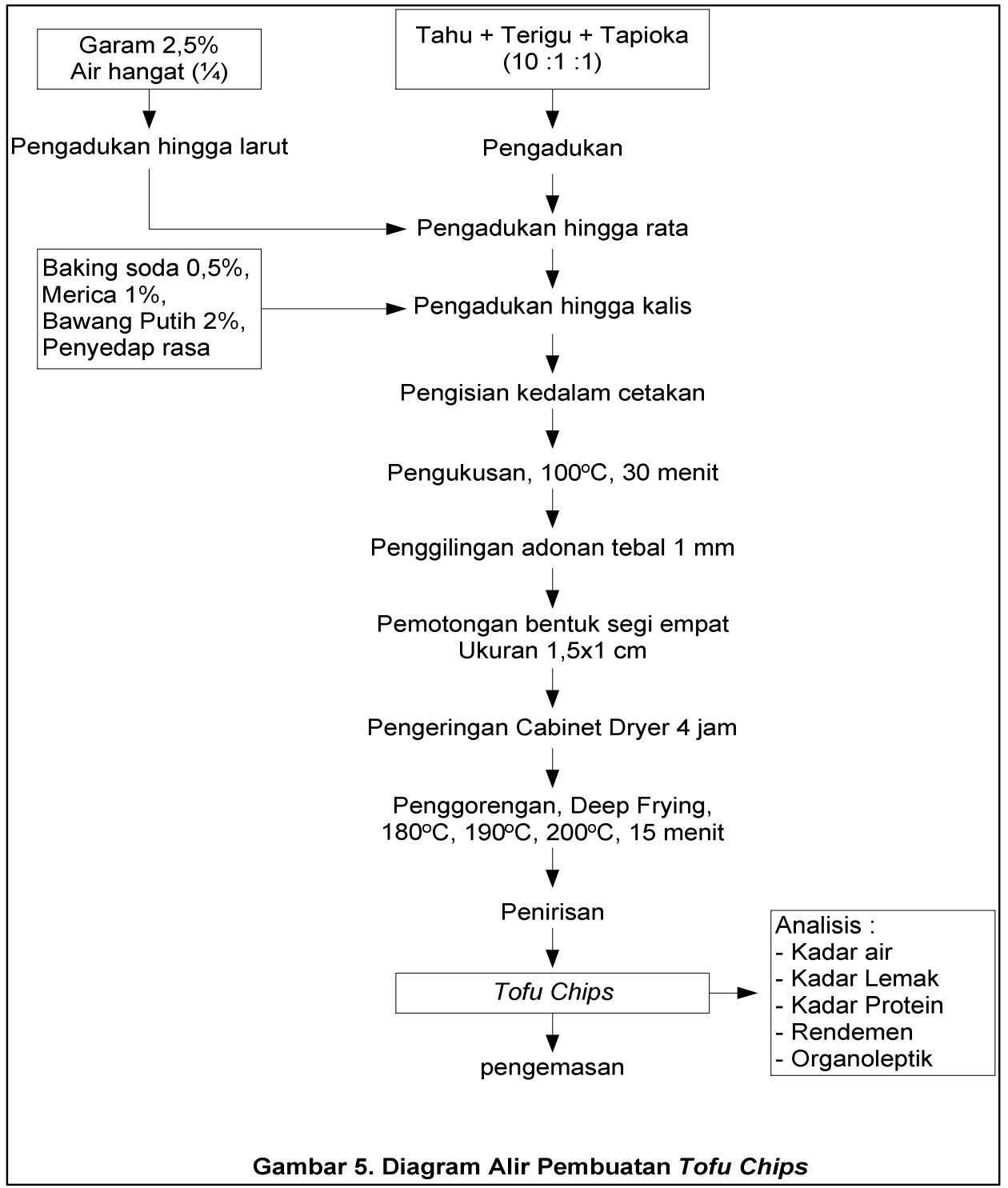


cukup tinggi, sehingga tekstur dan kerenyahan produk dapat dipertahankan dalam waktu yang lama.

\section{Perencanaaan Kapasitas Produksi}

Kapasitas produksi dari suatu pabrik atau industri yang akan didirikan, dapat dilakukan dengan dua cara pendekatan. Pertama adalah dengan memperkirakan tingkat permintaan potensial terhadap produk pada masa depan, sedangkan kedua adalah dengan pendekatan terhadap ketersediaan bahan bakunya.

Menurut Suratman (2001), Konsep yang paling sederhana dalam menentukan skala operasi (luas

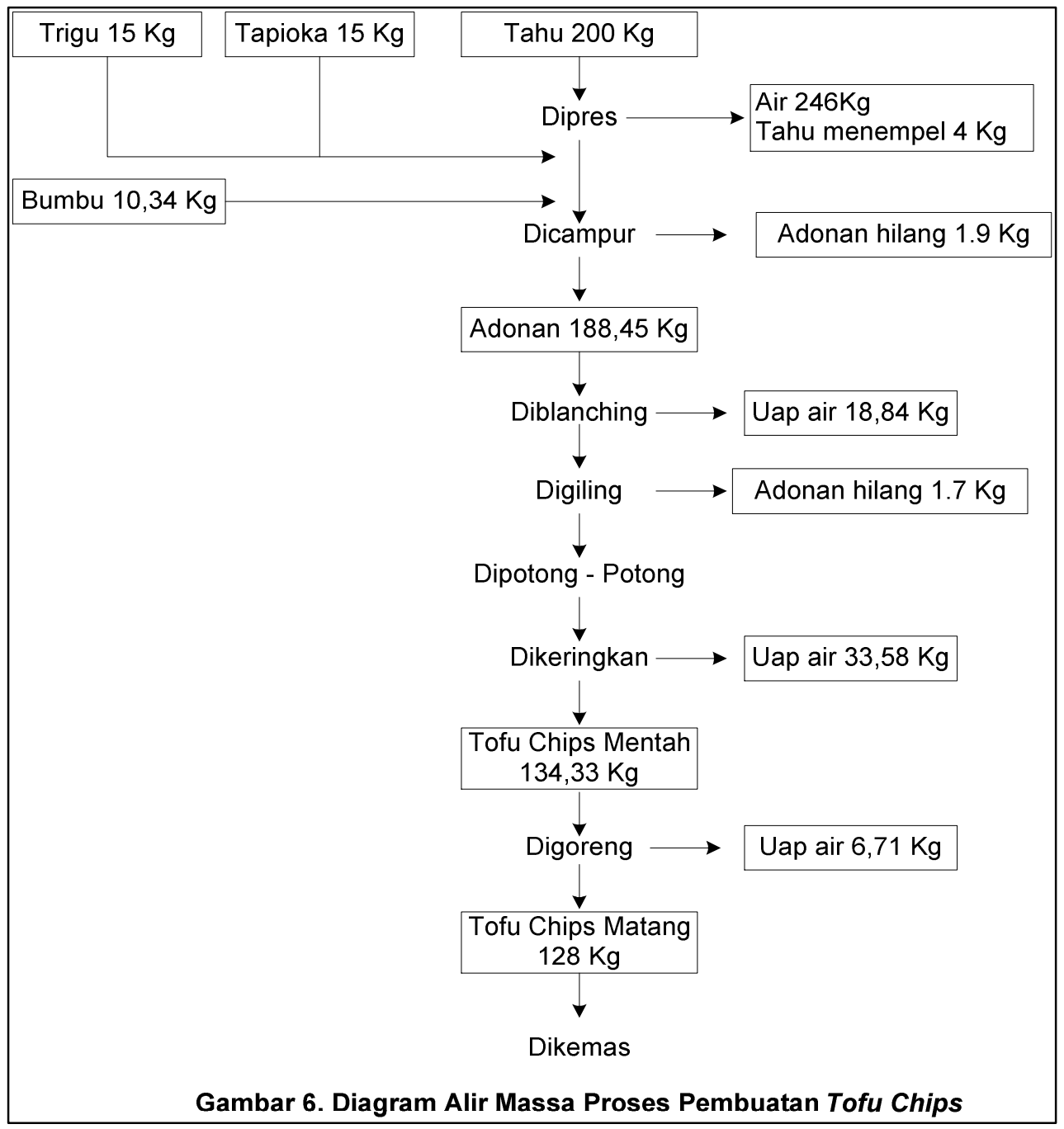


produksi) adalah bergantung pada kemungkinan perkembangan pangsa pasar (market share) yang dapat diraih dan kapasitas mesin serta peralatan yang dimiliki perusahaan serta dengan memperhatikan kualitas dan kuantitas sumberdaya manusia dalam proses produksi, kemampuan keuangan perusahaan dan kemungkinan adanya perubahan teknologi produksi di masa yang akan datang.

Kapasitas produksi yang direncanakan didasarkan pada pertimbangan skala usaha, kemampuan mesin dan peralatan, sehingga ditetapkan kapasitas produksi per hari $128 \mathrm{~kg}$. Dari hasil penelitian pendahuluan yang telah dilakukan, diketahui rendemen dari tofu chips yang telah dibuat adalah sebesar 29,06\%. Sehingga diperkirakan kebutuhan bahan baku untuk satu hari kerja adalah 400 $\mathrm{kg}$ tahu, $15 \mathrm{~kg}$ tepung tapioka, $15 \mathrm{~kg}$ Tepung trigu, 3,6 kg garam, $0,74 \mathrm{~kg}$ baking soda, $1,5 \mathrm{~kg}$ penyedap rasa, $3 \mathrm{~kg}$ bawang putih, dan $1,5 \mathrm{~kg}$ mrica

\section{Kebutuhan Bahan Baku}

Bahan - bahan yang digunakan dalam industri tofu chips adalah :

\section{a. Tahu Putih}

Bahan baku ini dipilih berdasarkan dari hasil penelitian lapang yang menunjukkkan tofu chips yang berbahan baku dari tahu putih lebih banyak disukai daripada tofu chips yang berbahan baku dari tahu takwa kuning. Tahu putih ini didapatkan dari industri pembuatan tahu yang ada diberbagai wilayah jawa timur khususnya di kota Malang dan kota Kediri yang dikenal sebagai sentra industri tahu yang cukup besar. Bentuk tahu yang dipakai kubus dengan ketebalan sekitar 3-4 cm, struktur kenyal dengan kadar air sekitar $37,5 \%$ dengan harga Rp. $2.000,00$ per $\mathrm{kg}$.

b. Tepung Trigu

Tepung trigu yang digunakan adalah tepung trigu dengan merk dagang segi tiga biru karena tepung trigu ini memiliki kadar gluten yang rendah sehingga akan meningkatkan kerenyahan produk. Harga tepung trigu dipasaran eceran Rp. 4.500,00 per kg.

c. Tepung Tapioka

Tepung tapika ditambahkan untuk meningkatkan kerenyahan produk. Tepung tapioka ini didapat dari pasar dengan harga eceran Rp. $3.000,0$ per $\mathrm{kg}$.

Pada industri skala usaha kecil menengah (UKM) ini persedianan bahan baku tahu direncanakan pengadaan tiap dua hari sekali karena tahu memiliki umur simpan yang relatif pendek, sedangkan tepung trigu dan tepung tapioka direncanakan tiap bulan atau 25 hari kerja. Pengadaan bahan baku perlu direncanakan agar proses produksi dapat berjalan lancar tanpa terjadi kekurangan persediaan ataupun kelebihan persediaan yang terlalu besar (Asri dan Suprihanto, 1986). Jumlah bahan baku yang dibutuhkan untuk memenuhi kebutuhan produksi perbulan dapat dilihat pada Tabel . 
Tabel - Kebutuhan Bahan Baku Selama Satu Bulan

\begin{tabular}{|l|l|c|}
\hline No & \multicolumn{1}{|c|}{$\begin{array}{c}\text { Jenis } \\
\text { Persediaan }\end{array}$} & Jumlah \\
\hline 1 & Tahu Putih & $10000 \mathrm{~kg}$ \\
\hline 2 & Tepung Trigu & $375 \mathrm{~kg}$ \\
\hline 3 & $\begin{array}{l}\text { Tepung } \\
\text { Tapioka }\end{array}$ & $375 \mathrm{~kg}$ \\
\hline
\end{tabular}

Tabel diatas menunjukkkan kebutuhan bahan baku yang digunakan dalam industri tofu chips skala rumah tangga dengan kapasitas produksi 128 $\mathrm{kg}$. per hari dengan hari kerja efektif 25 hari untuk tiap bulannya

\section{Kebutuhan Tenaga Kerja}

Tenaga kerja merupakan bagian dari suatu industri yang penting, mengingat tugas dari tenaga kerja yang meliputi pengawasan dan pelaksanaan produksi, mulai dari penyiapan bahan baku, proses konversi sampai distribusi produk jadi (Schroeder, 1997).

Tabel. Kebutuhan Tenaga Kerja

\begin{tabular}{|l|c|}
\hline \multicolumn{1}{|c|}{ Proses } & Waktu Proses (Menit) \\
\hline Penimbangan & 50 \\
\hline Pengepresan & 60 \\
\hline Pencampuran & 90 \\
\hline Pemipihan & 30 \\
\hline Pengukusan & 180 \\
\hline Pengilingan & 240 \\
\hline Pemipihan & 240 \\
\hline Pengirisan & 240 \\
\hline Pengeringan & 480 \\
\hline Penggorengan & 240 \\
\hline Penirisan & 60 \\
\hline Pengemasan & 122 \\
\hline Total & $2032(33,86$ jam) \\
\hline
\end{tabular}

Industri tofu chips direncanakan dalam skala usaha kecil menengah (UKM), sehingga tenaga kerja yang diperlukan tidak begitu banyak. Jumlah tenaga kerja yang digunakan didasarka pada peta proses operasi yang dapat dilihat pada lampiran 17 Perencanaan kebutuhan tenaga kerja ini didapat dari total waktu produksi dibagi dengan ketersediaan jam kerja.

Pada Tabel dapat dilihat bahwa kebutuhan operasional perhari adalah 33,86 jam. Waktu kerja direncanakan 7 jam/hari per orang. Dengan demikian industri ini membutuhkan 5-6 orang tenaga kerja untuk kegiatan proses produksi. Bagian administrasi dan pemasaran masing-masing membutuhkan satu orang tenaga kerja. Tenaga kerja untuk proses produksi direncanakan menggunakan sistem kontrak sehingga upah diberikan apabila proses produksi berlangsung dan sebaliknya jika tidak produksi upah tidak diberikan sedangkan tenaga kerja pada bagian administrasi dan pemasaran diberikan gaji tetap tiap bulannya. Perhitungan biaya tenaga kerja dalam produksi perlu dicatat sebagai dasar untuk menetapkan upah (Gitosumarmo, 1984).

\section{Kebutuhan Mesin dan Peralatan Produksi}

Faktor-faktor yang perlu dipertimbangkan dalam pemilihan jenis teknologi antara lain jenis teknologi yang diajukan harus cocok dengan persyaratan yang diperlukan untuk mencapai kapasitas produksi ekonomis yang ditentukan, perhitungan jumlah dana yang diperlukan untuk pembelian mesin dan peralatan yang dibutuhkan, pengaruhnya terhadap biaya 
produksi/satuan barang yang akan diterapkan secara berhasil ditempat lain dihasilkan dan kepastian apakah jenis (Sutojo, 1996) teknologi yang dipilih pernah

Tabel . Spesifikasi Mesin dan Peralatan Industri Tofu Chips

\begin{tabular}{|c|l|c|l|l|}
\hline No & \multicolumn{1}{|c|}{ Nama Mesin } & Jmlah & \multicolumn{1}{c|}{ Fungsi } & \multicolumn{1}{c|}{ Spesifikasi } \\
\hline 1 & Bak Penampung & 4 & Mencampur adonan & $\begin{array}{l}\text { Plastik } \varnothing 1 \mathrm{~m}, \\
\mathrm{t}=0,45 \mathrm{~m}\end{array}$ \\
\hline 2 & Timbangan & 1 & Menimbang & Kapasitas 100 kg \\
\hline 3 & Sealer & 1 & Mengemas & Impulse Sealer \\
\hline 4 & Pres Hidrolik & 1 & Mengurangi kadar air tahu & Kapasitas 5 kg \\
\hline 5 & Pengering Rak & 1 & Mengeringkan & Stainless steel, 4 pintu, 80 rak \\
\hline 6 & Kompor & 4 & Pemanas & Merk "Hook" 64 sumbu \\
\hline 7 & Dandang & 4 & Mengukus & Aluminium "Gajah" kap 20 L \\
\hline 8 & Penggiling Roti & 2 & Memipihkan adonan & Stainless Steel 6 skala \\
\hline
\end{tabular}

\section{Proses Produksi}

Produksi tofu chips direncanakan dalam satu hari satu kali proses, waktu kerja direncanakan 7 jam/hari per orang. Total waktu proses yang dibutuhkan untuk memproduksi sebanyak $128 \mathrm{~kg}$ tofu chips adalah 2032 menit atau 33, 86 jam (Peta Proses Operasi : Gambar 4). Waktu 2032 menit tersebut terdiri dari 1850 waktu proses dan 180 menit waktu delay dan 2 menit untuk storage. Waktu terlama terdapat pada proses pengeringan, yang membutuhkan waktu 240 menit atau 4 jam.

Jumlah tenaga kerja yang digunakan pada proses produksi tofu chips ini dihitung berdasarkan pendekatan lamanya waktu proses produksi tofu chips yang diperlukan dibagi dengan jam kerja yang tersedia, sehingga jumlah tenaga kerja yang diperlukan untuk proses produksi sebanyak 5-6 orang.

\section{ANALISIS BIAYA PRODUKSI}

Analisis biaya produksi dilakukan untuk mengetahui tingkat kelayakan industri yang akan direncanakan. Analisis biaya produksi yang dilakukan pada perencanaan industri tofu chips skala usaha kecil menengah (UKM) ini meliputi biaya produksi (BP), Break Even Point (BEP) dan Payback Periods (PP).

Investasi awal dalam pendirian industri tofu chips skala usaha kecil menegah (UKM) ini adalah sebesar Rp. 139.160.950,00. Investasi awal diperoleh dari hasil penjumlahan modal tetap dengan modal kerja selama tiga bulan. Modal tetap yang direncanakan Rp. 45.410.200,00 nilai ini diperoleh dari penjumlahan dari biaya investasi ruang produksi dan kantor, biaya instalasi, biaya investasi peralatan produksi, peralatan kantor dan sarana tranportasi. Sedangkan kebutuhan modal kerja selama tiga bulan adalah Rp. 93.750.750,00 nilai ini diperoleh 
dari hasil penjumlahan biaya bahan baku produksi, bahan pembantu, bahan pengemas, utilitas, biaya penyusutan peralatan, gaji tenaga kerja dan biaya administrasi selama tiga bulan kerja. Modal kerja yang digunakan diasumsikan modal kerja sendiri tanpa meminjam ke bank, sehingga aliran kas bunga bank tidak diperhitungkan.

Kapasitas produksi pertahun yang direncanakan adalah 384.000 kemasan dengan berat tiap kemasan adalah 100 gram harga pokok penjualan (HPP) adalah Rp. 977,08 sedangkan harga jualnya direncanakan Rp. 1400,00 dengan mark up sebesar $40 \%$. Jumlah produk yang terjual diasumsikan sebesar $90 \%$ dari produk yang diproduksi. Pada tahu pertama pendapatan bersih yang diterima oleh perusahaan sebesar Rp. 108.917.800,00.

Hasil analisa Break Even Point (BEP) menunjukkan bahwa kapasitas produksi yang direncanakan memberikan keuntungan bagi perusahan. Dengan kapasitas produksi sebesar 384.000 kemasan per tahun di dapat titik impas dengan memproduksi tofu chip sebanyak 42517 Kemasan. Payback Periode(PP) didapat pada 3 tahun 9 bulan Ohari dengan asumsi tingkat produksi tetap dan harga stabil pada tingkat inflasi $6,5 \%$.

\section{KESIMPULAN DAN SARAN}

\section{Kesimpulan}

Berdasarkan hasil penelitian dan perhitungan yang telah dilakukan, produk terpilih adalah S1T3 ( Tofu Chips yang berbahan baku dari tahu putih dengan suhu penggorengan sebesar $200^{\circ} \mathrm{C}$ ). yang akan menghasilkan tofu chips dengan kadar protein $20,57 \%$, kadar lemak 8,67 \%, kadar air 0,076 \%, dan rendemen sebesar 20,23 \%. Produk S1T3 mempuyai nilai perlakuan tertinggi ini menunjukan produk ini yang dipilih oleh konsumen dengan skor 2,653.

Investasi awal yang dibutuhkan untuk mendirikan industri tofu chips dengan kapasitas produksi $128 \mathrm{~kg}$ per hari adalah sebesar Rp. 139.160.950,00. Harga Pokok Produksi (HPP) didapat sebesar Rp. 977,08 per kemasan dengan berat 100 gram, harga jual yang direncanakan sebesar Rp. 1400 dengan penambahan mark up sebesar $40 \%$, Break Even Point (BEP) terjadi pada volume penjualan 42517 kemasan senilai Rp. 59.344.554,46. Payback Periode (PP) adalah 3 tahun 9 bulan.

\section{Saran}

Perlu dilakukan penelitian lebih lanjut tentang umur simpan produk tofu chips khususnya berkaitan dengan kerenyahan produk yang dihubungkan dengan jenis kemasan yang cocok digunakan.

\section{DAFTAR RUJUKAN}

Anonymous. 2003. Konsumsi Penduduk Jawa Timur Tahun 2002 Berdasarkan Data Modul Konsumsi Survey Sosial Ekonomi Masional (Susenas) 2002. BPS Prop. Jawa Timur. Surabaya. 
Apriantono, A. 2002. Pengaruh

Pengolahan Terhadap Nilai

Gizi Dan Keamanan Pangan.

Makalah ini disampaikan pada

Seminar Online Kharisma ke-2,

www. kharisma.com. tanggal

akses 15 April 2005

Asri, M. dan J. Suprihanto. 1986. Manjemen Perusahaan Pendekatan Operasional. BPFE. Yogyakarta.

Atmosudirdjo, S. P. 1982. Beberapa Pandangan Umum Tentang Pengambilan Keputusan (Decisions making). Ghalia Indonesia. Jakarta

DeGarmo, E.P., W.G. Sullivan and J.R. Canada. 1984. Engineering Economy. Macmillan Publishing Company. New York.

Fellow, P. 1990. Food Processing Technology. Principles and Practice. Ellis Horwood Limited. West Sussex. England

. 1992. Dehydration dalam Hui, Y. H. (ed.). 1992. Encyclopedia of Food Science and Technology. Vol. 1. pp. $556-$ 575. John Willey \& Sons, Inc. New York.

Gruenwald, G., 1997. New Product Development. NCT Business Books, USA

Harris, R. S. Dan E. Karmas. 1989. $\begin{array}{lcr}\text { Evaluasi } & \text { Gizi } & \begin{array}{r}\text { pada } \\ \text { Pengolahan }\end{array} \\ \text { Bahan } & \text { Pangan. }\end{array}$
Terbitan ke-2. Penerbit ITB. Bandung.

Husnan S. dan suwarsono. 1999. Studi Kelayakan Proyek. Unit Penerbit dan Percetakan (UPP) AMP YKPN. Yogyakarta.

Indrasari, S., dan Darmardjati, D. S. !991. Sifat Fisik dan Kimia Varietas Kedelai dan Hubungannya Dengan Rendemen Dan Mutu Tahu. Media Penelitian Sukamandi. 9: 43-49

Ketaren, S. 1986. Pengantar Teknologi Minyak dan Lemak Pangan. UI-Press. Jakarta.

Koswara, S. 1995. Teknologi Pengolahan Kedelai. Pustaka Sinar Harapan. Jakarta

Kotler, P. Alih Bahasa, Teguh H. dkk. 2002, Manajemem Pemasaran. PT. Prenhallindo. Jakarta

Kusnadi, Nanang, S. Dan Jahroh. 1999. Akutansi Biaya. Fakultas Ekonomi Universitas Ahmad Yani. Bandung

Luh, H. 1980. Rice Production and Utillization. The Avi Publishing Company. Inc. Westport. Connecticut

Mangkusubroto, K. Dan Trisnadi, C. L. 1987. Analisa Keputusan Pendekatan Sistem dalam Manajemen Usaha Proyek. Ganeca Exacta. Bandung

Mahmud, M. K., D. S. Slamet, R. R. Apriantono dan Hermana. 1990. 
Komposisi Zat Gizi Pangan Indonesia. Dep. Kes. RI. Direktorat Bina Gizi Masyarakat dan Pusat Penelitian dan Pengembangan gizi. Jakarta

Mien, K. M. et. Al. 1990. Komposisi Zat Gizi Pangan Indonesia. Dep. Kes. RI. Direktorat bina Gizi. Pusat Penelitian dan Pengembangan Gizi. Jakarta

Mulyadi. 1997. Akutansi Manajemen Konsep Manfaat dan Rekayasa. STIE YKPN. Yogyakarta

Muchtadi, D., T. R., Purwiyatino dan A. Basuki. 1987. Teknologi Pemasakan Ekstrusi. Pusat Antar Universitas. IPB. Bogor

Schroeder, F. 1997. Food Packaging. The AVI Publishing Company Inc. West Port Connecticut. United Staters Of Amerika.

Soekarto, S. T. 1985. Penilaian Organoleptik untuk Industri Pangan dan Hasil Pertanian. PT. Bhratara Karya Aksara. Jakarta

Sulistyowati, A. 2004. Membuat Kripik Buah dan Sayur. Puspa Swara, Anggota IKAPI. Jakarta

Suprapti, L. M. 1997. Seputar Penanganan Kedelai dalam Industri dan Rumah Tangga. Vidi Ariesta. Surabaya
Suratman. 2001. Studi Kelayakan Proyek: Teknik dan Prosedur Penyusunan Laporan. Edisi pertama. J\&J Learning. Yogyakarta.

Sutojo, S., 1996, Studi Kelayakan Proyek, Teori dan Praktek, PT. Pustaka Binaman Pressindo, Jakarta.

Urlich, Kart T. and Epinger, Steven D. Eppinger . 2000 Perancangan dan Pengembangan Produk. Diterjemahkan oleh Azmi, nora dan Iveline A. M. 2001 Salemba Teknika. Jakarta.

Van Arsdel, W. B., M. J. Coply, And A. I. Morgan. 1973. Food Dehydration, Methods and Phenomena. Vol. 1. 2nd ed. The AVI Publishing Company, Inc. Westport. Connecticut

Vickers, Z. 1979. Crispness and Crunchiness of Food in Food Texture and Theologi. Academic Press. London

Wang, H. L., Swain, E. W., dan Kwolek, W. F. 1984. Effect Of Soybean Varietas On The Yield And Quality Of Tofu. Cereal Chemistry. 60:245-248

Widyawati, W. 1996. Indentifikasi Variabel yang Berpengaruh Terhadap Tumbuh Kembang Industri Tahu di Kota Kediri. Skripsi Fak. Pertanian. Universitas Brawijaya. Malang 
